\title{
PERCEIVED STRESS AMONG NURSES DURING COVID-19 OUTBREAK
}

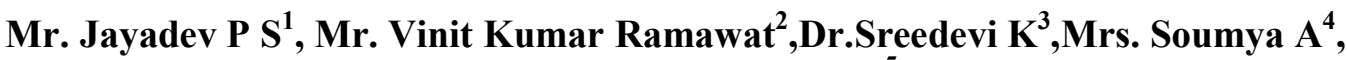 \\ Mr. YashawantRamawat ${ }^{5}$ \\ ${ }^{1}$ Assitant Professor, Birla College of Nursing, Pilani \\ ${ }^{2}$ Assistant Professor, Birla College of Nursing, Pilani \\ ${ }^{3}$ Professor, Birla College of Nursing, Pilani \\ ${ }^{4}$ Associate Professor, Birla College of Nursing, Pilani \\ ${ }^{5}$ Nursing Officer, AIIMS, Jhodhpur
}

\section{Corresponding Author Email: researchinnovators.in@gmail.com,}

\begin{abstract}
:
Introduction: The outbreak of the Novel Corona virus (COVID-19) hasspread worldwide causing an ongoing pandemic. During an outbreak of a new pandemic such as COVID-19, uncertainty and anxiety develop as the overall situation changes suddenly. Hencea study was conducted to assess the level of stress perceived by nurses working in selected COVID designated hospitals in India.
\end{abstract}

Materials and Methods: A Descriptive Cross Sectional Survey was conducted using Purposive Sampling Technique. A total of 190 nurses were participated in the study.

Results: The survey report showed a moderate level of stress perceived by the majority of nurses. There was a statistically significant association found between perceived levels of stress with demographic variables like age, education, and experience at $\mathrm{p}<0.05$ level, but no significant association existed between gender and level of stress perceived.

Conclusion: Effective management of pandemic should be a priority for healthcare organizations and adequate training has to be given for health care workers.

Key words: COVID-19, Nurses stress, PSS-10, Perceived stress

\section{INTRODUCTION:}

The outbreak of a pandemic and catastrophic effect on mankind has been dealt with in the past decades. An increasing level of stress among health care professionals is witnessed currently due to the ongoing pandemic of COVID19 outbreak. $^{(1)}$ Nurses are particularly vulnerable to infection due to frequent patient nurse interactions, direct contact with respiratory fluids of infected patients and inadequate protective gears. United Nation (UN) in 1992 declared that job stress is the disease of 20th century and later, World Health Organization (WHO) stated that it is epidemic. ${ }^{(2)}$ Nurses play a pivotal role as direct care givers and are subject to high degree of stress due to lack of resources, physical exhaustion, difficulty in balancing work and responsibility which eventually contribute to health issues in nurses. This increased level of stress decreases their efficiency and reflect to a great extent on patient care. A study by Kim HC et al.(2006) ${ }^{(3)}$ investigated the relationship between job 
stress and psychosocial stress among nurses at a university hospital in Korea, in that study the groups with high stress had insufficient job control, interpersonal conflict, job insecurity and were more likely to experience high psychosocial stress.A better understanding of the perception of stress by nurses and other health care professionals may provide new insight to develop better support to nurses during an infectious outbreak. Hence a study is designed to assess the level of stress perceived by nurses during COVID19 outbreak. Objectives are 1) To assess the level of stress perceived by nurses.2) To associate the level of stress with selected demographic variables.

\section{MATERIALS AND METHODS:}

\section{Research Design andSampling}

Technique:ADescriptive Cross Sectional Survey was done using Purposive Sampling Technique to obtain data.

Data Collection Procedure:Owing to the current situation of quarantine and lockdown, a web based cross sectional survey was conducted from 21/06/2020 to $30 / 06 / 2020$ using an online questionnaire to a sample of nurses using Google forms to collect the data. The sample consisted of 190 nurses who were working in COVID designated hospitals.Each participant was contacted to make sure that he or she was a nurse working in hospitals. The questionnaire was anonymous to maintain the privacy and confidentiality of all information collected in the study. A web based survey consisting of 2 sections were used to assess the information:

1) Demographic data including age, gender,marital status, educational qualification, area of work, work experience and data related to COVID exposure.

2) Perceived Stress Scale (PSS-10), Cohenetal (1983) ${ }^{(4)}$ - A standardized scale was used, each item in the scale was answered by the participants on a fivepoint Likert scale ranging from never (0) to very often (4) with a total score of 0 to 40. PSS scores range from ( 0 to 13 ) is low stress; (14 to 26) is moderate stress(27 to 40) is high perceived stress.

The online questionnaire consisted of brief introduction to title, objective, voluntary nature of participation, declaration of anonymity and confidentiality. The participant has to answer a 'YES' 'NO' question to confirm their willingness to participate voluntarily, after the confirmation, participants were directed to complete the self-reported questionnaire. Data wereanalyzed was presented under two sections: a) Perceived stress level of nurses during COVID-19 outbreak b) Association of selected socio demographic characteristics and perceived stress level. 


\section{RESULTS:}

Fig -1: Level of stress perceived by participants $N=190$

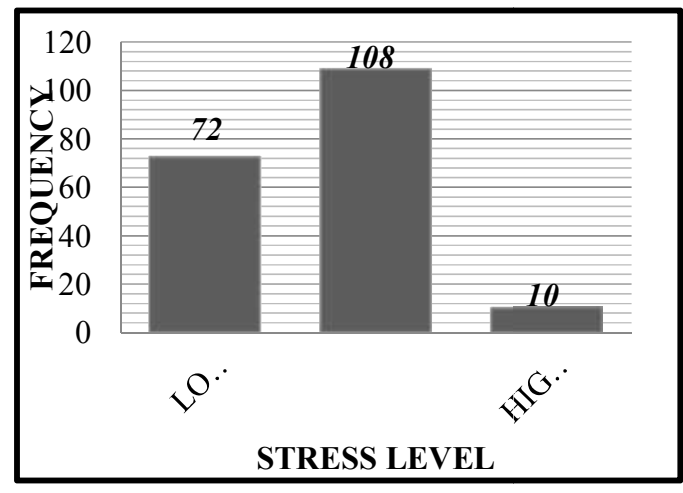

Fig 1 shows thatmajority of the participants $(56.8 \%)$ had perceived moderate level of stress.

Table 1: Association of stress level with selected Demographic Variables $\mathbf{N}=190$

\begin{tabular}{|c|c|c|c|c|c|c|}
\hline \multirow{2}{*}{$\begin{array}{c}\text { Variabl } \\
\text { es }\end{array}$} & \multirow{2}{*}{$\begin{array}{c}\text { Frequen } \\
\text { cy } \\
(\%)\end{array}$} & \multicolumn{3}{|c|}{ Level of stress } & \multirow{2}{*}{$\left(X^{2}\right)$} & \multirow{2}{*}{$\begin{array}{c}\text { P } \\
\text { Val } \\
\text { ue }\end{array}$} \\
\hline & & Low & $\begin{array}{c}\text { Mediu } \\
\text { m }\end{array}$ & High & & \\
\hline \multicolumn{5}{|c|}{ 1.Age } & \multirow{3}{*}{$\begin{array}{c}14.9 \\
9\end{array}$} & \multirow{3}{*}{$\begin{array}{l}.00 \\
05\end{array}$} \\
\hline $\begin{array}{c}<30 \\
\text { years }\end{array}$ & $\begin{array}{c}106 \\
(55.78 \%)\end{array}$ & $\begin{array}{c}30 \\
(15.78 \%)\end{array}$ & $\begin{array}{c}66 \\
(34.73 \\
\%)\end{array}$ & $\begin{array}{c}10 \\
(5.26 \\
\%)\end{array}$ & & \\
\hline $\begin{array}{l}\geq 30 \\
\text { years }\end{array}$ & $\begin{array}{c}84 \\
(44.21 \%)\end{array}$ & $\begin{array}{c}42 \\
(22.10 \%)\end{array}$ & $\begin{array}{c}42 \\
(22.10 \\
\%)\end{array}$ & 00 & & \\
\hline \multicolumn{5}{|c|}{ 2.Gender } & \multirow{3}{*}{$\begin{array}{c}1.76 \\
6\end{array}$} & \multirow{3}{*}{$\begin{array}{l}.41 \\
35\end{array}$} \\
\hline Male & $\begin{array}{c}104 \\
(54.73 \%)\end{array}$ & $\begin{array}{c}37 \\
(19.47 \%)\end{array}$ & $\begin{array}{c}63 \\
(33.15 \\
\%)\end{array}$ & $\begin{array}{c}4 \\
(2.1 \%)\end{array}$ & & \\
\hline Female & $\begin{array}{c}86 \\
(45.26 \%)\end{array}$ & $\begin{array}{c}35 \\
(18.42 \%)\end{array}$ & $\begin{array}{c}45 \\
(23.68 \\
\%)\end{array}$ & $\begin{array}{c}6 \\
(3.15 \\
\%)\end{array}$ & & \\
\hline \multicolumn{5}{|c|}{ 3.Educational Qualification } & \multirow{4}{*}{$\begin{array}{c}32.5 \\
5\end{array}$} & \multirow{4}{*}{$\begin{array}{c}0.0 \\
000 \\
1\end{array}$} \\
\hline Diploma & $\begin{array}{c}58 \\
(30.52 \%)\end{array}$ & $\begin{array}{c}39 \\
(20.52 \%)\end{array}$ & $\begin{array}{c}18 \\
(9.47 \%) \\
\backslash\end{array}$ & $\begin{array}{c}1 \\
(.526 \\
\%) \\
\end{array}$ & & \\
\hline $\begin{array}{c}\text { baccalau } \\
\text { reateDe } \\
\text { gree }\end{array}$ & $\begin{array}{c}99 \\
(52.10 \%)\end{array}$ & $\begin{array}{c}26 \\
(13.68 \%)\end{array}$ & $\begin{array}{c}65 \\
(34.21 \\
\%)\end{array}$ & $\begin{array}{c}8 \\
(4.21 \\
\%)\end{array}$ & & \\
\hline $\begin{array}{c}\text { Masters } \\
\text { and } \\
\text { Above }\end{array}$ & $\begin{array}{c}33 \\
(17.36 \%)\end{array}$ & $\begin{array}{c}7 \\
(3.68 \%)\end{array}$ & $\begin{array}{c}25 \\
(13.15 \\
\%) \\
\end{array}$ & $\begin{array}{c}1 \\
(.526 \\
\%) \\
\end{array}$ & & \\
\hline \multicolumn{5}{|c|}{ 4. Experience } & \multirow{4}{*}{$\begin{array}{c}26.0 \\
6\end{array}$} & \multirow{4}{*}{$\begin{array}{r}.00 \\
003\end{array}$} \\
\hline$<5$ years & $\begin{array}{c}101 \\
(53.15 \%)\end{array}$ & $\begin{array}{c}29 \\
(15.26 \%)\end{array}$ & $\begin{array}{c}63 \\
(33.15 \\
\%)\end{array}$ & $\begin{array}{c}9 \\
(4.73 \\
\%)\end{array}$ & & \\
\hline $\begin{array}{l}5-10 \\
\text { years }\end{array}$ & $\begin{array}{c}51 \\
(26.84 \%)\end{array}$ & $\begin{array}{c}16 \\
(8.42 \%)\end{array}$ & $\begin{array}{c}34 \\
(17.89 \\
\%)\end{array}$ & $\begin{array}{c}1 \\
(.53 \%)\end{array}$ & & \\
\hline$>10$ year & $\begin{array}{c}38 \\
(20 \%) \\
\end{array}$ & $\begin{array}{c}27 \\
(14.21 \%) \\
\end{array}$ & $\begin{array}{c}11 \\
(5.78 \%) \\
\end{array}$ & 00 & & \\
\hline
\end{tabular}

S- Significant $\quad(p<0.05) \quad$ NS-Non significant $(\mathrm{p}>0.05)$

Table 1 shows that out of 190 samples $106(55.78 \%)$ were below 30 years of age and $104(54.73 \%)$ were male participants in the study. With regard to education level $99(52.10 \%)$ of the participants were having baccalaureate degree and $101(53.15 \%)$ were having less than 5 years of experience.Chi-square value shows that there was statistically significant association between age, educational qualification and experience. There was no significant association found between gender of the participants and the perceived level of stress.

\section{DISCUSSION:}

The findings of the present study show thatmajority (108)nurses perceived moderate level of stress.This was similar to study by Alharbi $\mathrm{H}$, Alshehry A. $(2019)^{(5)}$ in which majority $(87 \%)$ experienced moderate level of stress. Another study byMozhdeh. S et.al (2018) (6) alsoshowed that majority of participants(55\%)were withmoderate level of stress.

Table 1 shows that there was significant association of perceived stress 
level with age, education and experience of the nurses participated in this studyand was similar to findings by Emmanuel. A \& Collins A. (2016) ${ }^{(7)}$, withstatistically significant association found betweenlevel of stress (Chi-square $=385.577, \mathrm{P}<.01)$ and age, but this was contrary to a study by Sharifah ZSY, (2011) ${ }^{(8)}$ on stress and its associated factors amongst ward nurses in Malaysia showing no statistical significance between age and perceived level of stress.Findings of current study showthat significant association between stress and year of experience. Nurses with less than five years of experience perceived more stress compared to other groups, which was similar to a study conducted by Mohanty K (2006) ${ }^{(9)}$ with significant relationship between year of experience and stress. The significant association between perceived level of stress and educational qualification according to this study was also supported by Maria A,Tahira. K(2012) ${ }^{(10)}$ in their studyon demographic differences and occupational stress. Statistically significant association was not found between gender and level of stress which was similar to a study by Dagget, T. et al. (2016) (11). Contrary to the finding on gender by Zinurova. E and DeHart.K (2018) ${ }^{(12)}$ showed that female gender was associated with higher level of stress ${ }^{(13)}$.

\section{CONCLUSION:}

Every organization should conduct a stress audit as an ongoing process and assess the magnitude of stress and analyze it to develop an action plan. Organizational support and new strategies should be developed to prevent stress and burnout among health care professionals.

\section{REFERENCES:}

1. Tsamakis K, Rizos E, Manolis AJ, et al.(2020).COVID-19 pandemic and its impact on mental health of healthcare professionals. ExpTher Med, 19(6), 3451-53.

2. Zakerian S, Rahmani A, AbbasiniaM et al. (2014). A survey of the relation between workload and quality of life. Pakistan journal of public health, 4(1), 6-7.

3. Kim HC, Kwon KS,Koh DH et al., (2006). The Relationship between Job Stress and Psychosocial Stress among Nurses at a University Hospital.

Korean J Occup Environ Med, 18(1), 25-34.

4. Cohen, S., Kamarck, T., \&Mermelstein, R. (1983). A global measure of perceived stress.Journal of Health and Social Behavior, 24, 38596.

5. Alharbi H, Alshehry A. (2019). Perceived stress and coping strategies among ICU nurses in government tertiary hospitals in Saudi Arabia: a cross-sectional study. Ann Saudi Med, 39 (1), 48-55.

6. Mozhdeh S, Sabet B, Irani MD, Hajian E, Malbousizadeh M.(2008). 
Relationship between nurse's stress and environmental - occupational factors. Iranian Journal of Nursing and Midwifery Research, 13(1), 1-5.

7. Emmanuel. A \& Collins A. (2016). Relationship between Occupational Stress and Demographic Variables: A Study of Employees in a Commercial Bank in Ghana. British Journal of Applied Science \& Technology. 12, 19.

8. Sharifah ZSY, Afiq IM, Siti SD. (2011). Stress and its associated factors amongst ward nurses in a public hospital Kuala Lumpur. Malaysian J. Public Health Med, 11(1), 78-85

9. Mohanty K. (2006) Occupational stress and job satisfaction of nurses working in psychiatric hospital. (unpublished dissertation) Karnataka; RGUHS.
10.Maria.A,Tahira.K.(2012).

Demographic Differences and Occupational Stress of Secondary School Teachers. European Scientific J, 8 (5), 159-75.

11.Dagget, T., Molla, A. \&Belachew, T. (2016). Job related stress among nurses working in Jimma Zone public hospitals, South West Ethiopia: a cross sectional study. BMC Nurs, 15, 39.

12.Zinurova.E,DeHart.R.(2018).Perceived stress, stressors and coping mechanisms among PGY, pharmacy residents. American journal of pharmaceutical education, 82(7), 6574.

13. Shatrughanpareek et al.(2020). Assessment of knowledge and practice of urban population regarding Covid19: a cross-sectional study in Bikaner, Rajasthan.IJCMPH,7(8),3095-99. 